\title{
Optimasi Sistem Turbin Angin Menggunakan Maximum Power Point Tracking (MPPT) dengan Metode Particle Swarm Optimization (PSO)
}

\author{
Husein Mubarok ${ }^{1}$, Bibie Albar Whiancaka ${ }^{2}$ \\ 1,2Program Studi Teknik Elektro, \\ Fakultas Teknologi Industri, \\ Universitas Islam Indonesia, Yogyakarta \\ ${ }^{1}$ mubarok.husein@uii.ac.id, ${ }^{213524110 @ s t u d e n t s . u i i . a c . i d ~}$
}

\begin{abstract}
Abstrak
Permasalahan tentang krisis energi listrik, merupakan hal yang patut dikaji dalam beberapa dekade ini. Di mana mayoritas sumber energi listrik masih menggunakan bahan bakar fosil yang mulai habis dan tidak ramah lingkungan. Untuk itu, diperlukannya aksi serta perubahan untuk mulai beralih pada sumber energi alternatif yang berasal dari alam. Permasalahan terkait energi baru terbarukan sudah tak asing lagi dan telah dikembangkan, antara lain dengan Pembangkit Listrik Tenaga Hibrida (PLTH) yaitu merupakan pembangkit gabungan antara beberapa jenis pembangkit. Pada penelitian ini dibahas optimasi sistem turbin angin yang disimulasikan secara matematis dan menerapkan penggunaan Maximum Power Point Tracking (MPPT) dengan algoritma Particle Swarm Optimization (PSO). Hasil penelitian menunjukkan bahwa dengan optimasi tersebut menghasilkan daya keluaran yang lebih optimal dan efisisen, serta respon yang baik terhadap perubahan kecepatan angin.
\end{abstract}

Kata kunci: optimasi, energi terbarukan, turbin angin, MPPT, PSO

\begin{abstract}
The electric power shortage problem has been studied in the past decades. The majority of electric energy resources are still heavily relied on unrenewable and not eco-friendly fossil based fuels. Therefore, we need to start doing action for shifting to alternatives energy resources which is renewable and originated from nature. The problems regarding to new and renewable energy have been addressed, including Hybrid Power Plants which combine several types of power plants. In this research, we discussed an optimization of wind turbine systems which is simulated mathematically, and applied the Maximum Power Point Tracking (MPPT) using Particle Swarm Optimization (PSO) algorithm. The research shows that such optimization generates more optimum and efficient output power, and satisfactory response to the change of wind velocity.
\end{abstract}

Keywords: optimization, renewable energy, wind turbine, MPPT, PSO

\section{Pendahuluan}

Sebagai negara berkembang, Indonesia mempunyai kebutuhan energi listrik yang terus meningkat setiap tahunnya. Perkembangan pesat pada seluruh sektor dalam rangka 
mendukung kehidupan yang lebih modern memerlukan sumber daya energi yang memadai, terutama energi primer yaitu energi listrik. Sehingga perlu adanya energi terbarukan untuk mengatasi lonjakan kebutuhan energi listrik tersebut. Hal ini sesuai dengan kebijakan untuk memanfaatkan sumber energi nasional untuk memprioritaskan peningkatan dan optimasi pencapaian energi terbarukan tahun 2025 sejumlah 5\% [1], Sumber energi terbarukan dapat menjadi langkah alternatif sebagai sumber pembangkit energi listrik yang tetap tertuju pada aspek teknis, keselamatan lingkungan dan ekonomi di Indonesia.

Salah satu faktor penghambat pada sistem turbin angin adalah pada ranah rancangan sistem pembangkit yang kurang responsif ketika kecepatan angin yang berubah-ubah [2][7]. Berdasarkan hasil penelitian sebelumnya, untuk mengoptimalkan daya keluaran sistem turbin angin, perlu dilengkapi dengan MPPT serta terdapat berbagai macam metode. Dan penggunaan metode PSO mampu memberikan respon yang baik untuk sistem turbin angin dengan kecepatan angin yang berubah-ubah, dibanding metode optimasi lainnya yang membutuhkan peralatan pengukuran serta input parameter data yang kompleks atau hasil respon sistem yang kurang baik. Tujuan penelitian ini adalah untuk memperoleh desain sistem turbin angin yang dilengkapi MPPT dengan metode PSO sehingga mampu beradaptasi dengan kecepatan angin yang berubah-ubah. Tujuan selanjutnya adalah untuk mengetahui seberapa besar peningkatan efisiensi sistem turbin angin serta kinerja turbin angin pada saat kecepatan angin yang berubah-ubah.

\section{Tinjauan Pustaka}

\subsection{Energi Angin}

Angin merupakan udara yang bergerak. Energi angin dikonversikan ke dalam bentuk energi lain seperti energi mekanik atau energi listrik. Proses konversi energi angin dapat dilakukan dengan menggunakan kincir atau disebut dengan turbin angin. Daya yang dihasilkan oleh energi angin berbanding lurus dengan kecepatan angin dan kerapatan udara sebagaimana ditunjukkan pada Persamaan (1) [8][9].

Dengan nilai :

$$
P_{m}=\frac{1}{2} \rho \pi R^{2} V^{3} C_{p}(\lambda . \beta)
$$

$$
\begin{array}{ll}
P_{m} & =\text { energi angin } \\
\rho & =\text { kerapatan udara }\left(\mathrm{kg} / \mathrm{m}^{3}\right) \\
R & =\text { jari-jari }(\mathrm{m}) \\
V & =\text { kecepatan angin }(\mathrm{m} / \mathrm{s}) \\
C_{p} & =\text { koefisien performa turbin } \\
\lambda & =\text { tip speed ratio } \\
\beta & =\text { blade pitch }
\end{array}
$$

\subsection{Turbin Angin}

Turbin angin berfungsi untuk mengkonversikan energi angin menjadi energi mekanik sesuai persamaan (1). Koefisien performa turbin angin $\left(C_{p}\right)$ mereprensentasikan efisiensi ekstraksi daya pada turbin angin. $C_{p}$ merupakan fungsi non linier dari tip speed ratio $(\lambda)$ dan blade pith angle $(\beta)$. Secara teoritis $C_{p}$ memiliki nilai maksimum 0,59 sebagaimana ditunjukkan pada Gambar 1, akan tetapi dalam praktiknya nilai $C_{p}$ berkisar pada nilai 0,4 sampai dengan 0,45 [9]-[10]. 
TSR (Tip Speed Ratio) atau $\lambda$ merupakan variabel yang merepresentasikan perbandingan antara kecepatan linier ujung blade terhadap kecepatan putar dari turbin angin, berikut seperti ditunjukkan pada Persamaan (2).

$$
\lambda=\omega_{m} R / V_{w}
$$

Dengan nilai:

$$
\begin{array}{ll}
\lambda & =\text { kecepatan putar (tip speed ratio) } \\
\omega_{\mathrm{m}} & =\text { kecepatan anguler } \\
R & =\text { radius turbin }(\mathrm{m}) \\
V_{m} & =\operatorname{kecepatan} \text { angin }(\mathrm{m} / \mathrm{s})
\end{array}
$$

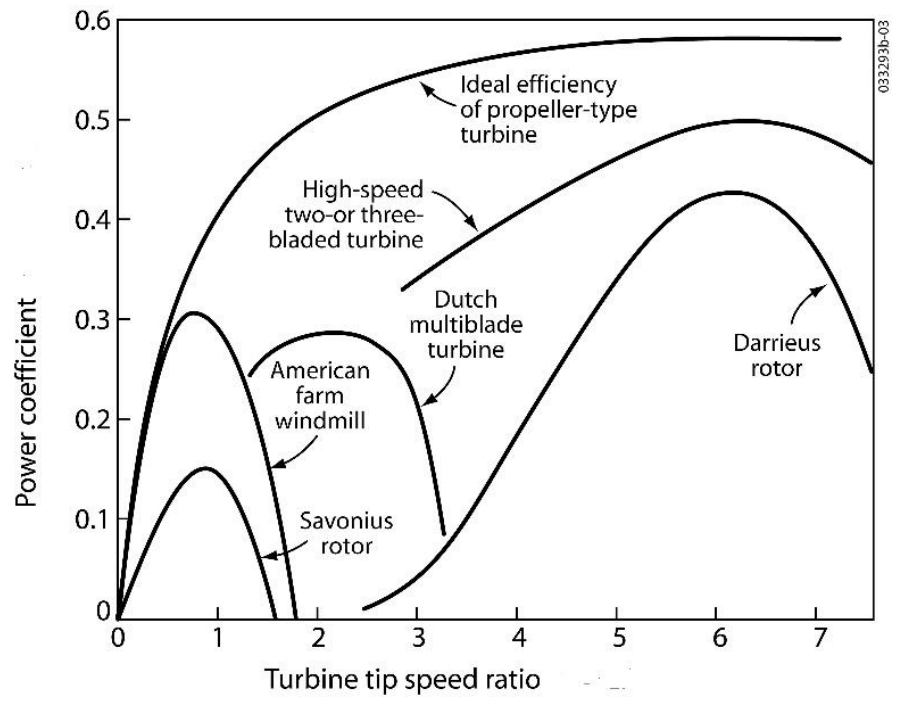

Gambar 1. Besar nilai TSR (Tip Speed Ratio) pada berbagai turbin angin

\subsection{Permanent Magnet Synchronous Generator (PMSG)}

Pada PMSG medan magnet yang diberikan tidak melalui elektromangetik melainkan melalui magnet permanen. Dalam hal ini fluks medan tetap konstan dan suplai untuk mengeksitasi kumparan medan tidak diperlukan begitu pula dengan keberadaan slip ring. Penggunaan PMSG dalam sistem mesin listrik memiliki beberapa keuntungan antara lain sebagai berikut [11] : 
1. Torsi dan daya keluaran yang dihasilkan lebih besar dibandingkan dengan eksitasi elektromagnetik

2. Respon dinamis yang lebih baik dibanding dengan menggunakan eksitasi elektromagnatik, dikarenakan rapat fluks pada air gap lebih tinggi

3. Rugi-rugi tembaga yang lebih kecil

4. Accoustic noise kecil.

5. Tidak ada energi listrik yang diserap oleh sistem eksitasi medan, dengan demikian tidak akan ada rugi-rugi eksitasi sehingga efisiensi akan meningkat

\subsection{Penyearah}

Penyearah atau rectifier berfungsi untuk mengubah listrik AC menjadi listrik DC. Hal ini sangat diperlukan dalam sistem turbin angin mengingat frekuensi listrik AC keluaran dari sistem sangat dipengaruhi oleh kecepatan angin. Semakin besar kecepatan angin maka frekuensi keluaran juga semakin besar. Oleh karena itu penyearah digunakan untuk mengubah listrik AC ke DC yang kemudian disalurkan ke beban atau diubah kembali menjadi listrik AC. Listrik DC yang diubah kembali ke AC dapat diatur nilai frekuensinya sesuai dengan kebutuhan dengan bantuan inverter [12]. Listrik AC keluaran PMSG akan disearahkan oleh penyerah dioda gelombang penuh tiga fase menggunakan sistem jembatan dengan enam buah diode. Tegangan rata-rata/DC keluaran penyearah tiga fase $\left(V_{0}\right)$ yang mana berbanding lurus dengan tegangan $\mathrm{AC}$ maksimum $(\mathrm{Vm})$ ditunjukkan pada Persamaan (3).

$$
V_{0}=1 / \frac{\pi}{3} \int_{\frac{\pi}{3}}^{\frac{2 \pi}{3}} V_{m} \sin (\omega t) \mathrm{d}(\omega t)=\frac{3 V_{m}}{\pi}=0,9555 V_{m}
$$

\subsection{Boost Converter}

DC Chopper tipe boost dapat mengubah suatu nilai tegangan DC tertentu menjadi tegangan DC yang lebih tinggi [13]-[14]. Rangkaian DC Chopper tipe boost menggunakan MOSFET sebagai switch-nya. Ketika MOSFET on dan dioda off maka arus mengalir menuju induktor dan terjadi proses pengisian arus pada induktor. Selanjutnya saat MOSFET off dan dioda on arus yang berada pada induktor akan dikeluarkan. Sehingga nilai arus antara sumber dan induktor merupakan penjumlahan antara arus pada sumber dan induktor. Pada saat yang bersamaan terjadi pula proses pengisian tegangan pada kapasitor sehingga ripple akan berkurang.

$$
\frac{V_{\text {out }}}{V_{\text {in }}}=\frac{1}{1-D}
$$

\subsection{Maximum Power Point Tracking (MPPT)}

MPPT merupakan suatu metode yang digunakan untuk mengoptimalkan daya keluaran suatu sistem. Pada sistem turbin angin variable speed, turbin angin dimungkinkan untuk beroperasi pada kecepatan yang optimal sebagai fungsi kecepatan angin. Kecepatan putar turbin dapat dikendalikan dengan konverter power electronic untuk mendapatkan daya maksimum yang dimungkinkan. Hal ini dapat dilakukan dengan menggunakan algortima MPPT sehingga daya keluaran dari turbin angin dapat optimal. Terdapat metode MPPT yang dapat digunakan dalam rangka mencapai efisiensi setinggi mungkin sesuai dengan kecepatan angin [15]. 


\subsection{Particle Swarm Optimization (PSO)}

Algoritma PSO pertama kali diperkenalkan pada tahun 1995 oleh Dr. Eberhart dan rekannya Dr. Kennedy. PSO didasarkan pada bentuk imitasi proses populasi hewan yang mencari sumber makanan seperti pada populasi ikan dan burung. Teknik optimasi ini adalah sebuah komputasi evolusioner yaitu pemecahan algoritmanya diawali pada sebuah populasi yang random atau disebut partikel.

Secara umum teknik optimasi yang berbasis pada populasi untuk mencari sebuah titik optimal atau solusi adalah menggunakan populasi dari partikelnya sendiri. Pencarian solusi yang optimal pada PSO mencakup ruang solusi yang berisi variabel-variabel optimasi yang disebut nilai obyektif atau nilai fitness. Nilai fitness ini adalah sebuah fungsi objektif masalah optimasi, dapat dianalogikan pada populasi burung sebagai kumpulan partikel yang mencari makanan. Dan fungsi tersebut adalah kualitas serta kuantitas makanan pada setiap tempat yang mereka cari. Sehingga kumpulan burung ini akan mencari tempat makanan dengan kuantitas paling banyak dan kualitas paling baik.

Selanjutnya partikel-partikel tersebut mempertahankan posisinya, nilai fitness yang terevaluasi, serta kecepatannya. Setiap partikel tersebut memiliki ingatan untuk menyimpan ke dalam memori, dengan kata lain menunjukkan nilai fitness terbaik $\left(P_{\text {best }}\right)$. Nilai fitness paling baik pada swarm atau kumpulan partikel ini disebut posisi global terbaik $\left(G_{b e s t}\right)$ [16]. Pada Persamaan (5), (6), (7), dan (8) ditunjukkan bentuk dari perubahan yang telah disesuaikan dengan permasahan optimasi seperti di bawah :

$$
\begin{gathered}
\left|\frac{p_{i}{ }^{k}-p_{i}^{k-1}}{p_{i}^{k}}\right|>\Delta P \\
|\operatorname{Max}(\Phi)|<\Delta \Phi_{\max } \\
\Phi_{\mathrm{i}}{ }^{\mathrm{k}+1}=W \Phi_{i}^{k}+c_{1} r_{1}\left\{d_{\text {Pbest }}^{k}-d_{i}^{k}\right\}+c_{2} r_{2}\left\{d_{\text {Gbest }}^{k}-d_{i}^{k}\right\} \\
d_{i}^{k+1}=d_{i}^{k}+\Phi_{i}^{k+1}
\end{gathered}
$$

Di mana nilai:$$
p_{i}{ }^{k} \quad=\text { daya sesudah (watt) }
$$$$
p_{i}^{k-1}=\text { daya sebelum (watt) }
$$$$
\Phi_{i}^{k} \quad=\text { kecepatan saat ini }
$$$$
\Phi_{i}{ }^{k+1}=\text { kecepatan termodifikasi }
$$$$
W \quad=\text { faktor momentum }
$$$$
d_{\text {Pbest }}^{k}=\text { personal best duty cycle }
$$$$
d_{\text {Gbest }}^{k}=\text { global best duty cycle }
$$$$
d_{i}^{k} \quad=\text { duty cycle saat ini }
$$$$
d_{i}^{k+1}=\text { duty cycle yang telah dimodifikasi }
$$$$
c_{1} c_{2} \quad=\text { konstanta akselerasi }
$$$$
r_{1} r_{2}=\text { nilai random antara } 0 \text { dan } 1
$$

\section{Metode Penelitian}

Sesuai dengan skema flowchart pada Gambar 2, penelitian ini dimulai dengan pengumpulan data karakteristik turbin angin. Data tersebut selanjutnya menjadi dasar perancangan MPPT dengan algoritma PSO dengan tujuan untuk mendapatkan daya keluaran sistem yang optimal [17]-[18].

Hasil rancangan dianalisis untuk mendapatkan efisiensi dan kinerja sistem turbin angin pada kecepatan angin yang berubah-ubah. Penelitian ini dilakukan dengan beberapa prosedur mulai dari analisis data turbin angin, karakteristik turbin angin, 
kemudian dilanjutkan dengan pemodelan sistem turbin angin sesuai dengan data karakteristik. Selanjutnya dilakukan pengimplementasian algoritma PSO pada MPPT untuk mendapatkan daya keluaran yang optimal pada kecepatan yang berubah-ubah. Pada tahap akhir dilakukan analisis terhadap daya keluaran turbin angin sehingga efisiensi sistem turbin angin yang dilengkapi dengan algoritma PSO pada MPPT dapat diketahui.

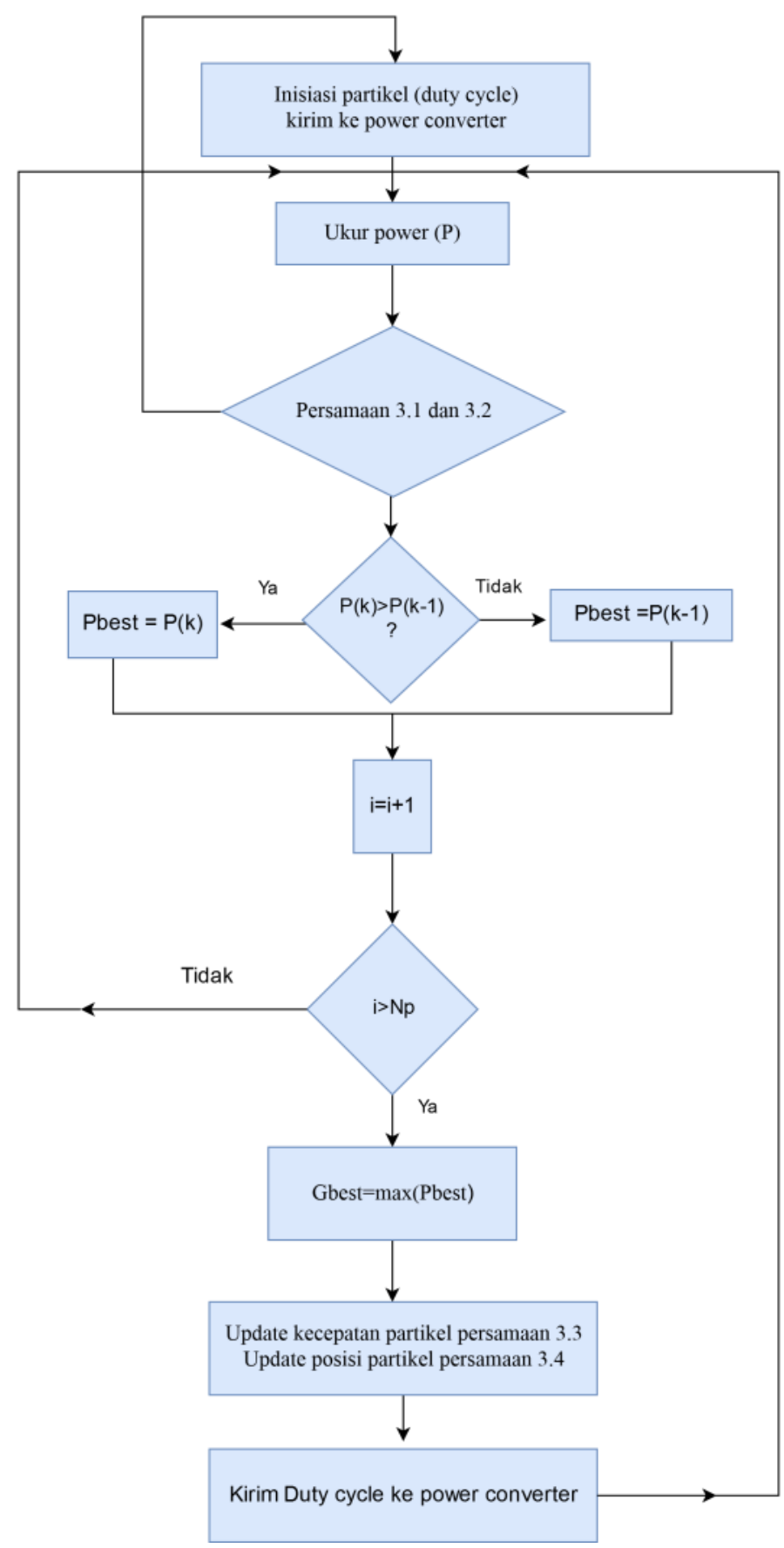

Gambar 2. Flowchart algoritma PSO 


\section{Hasil dan Analisis}

Berdasarkan data yang telah dikumpulkan, dapat dibuat sebuah model sistem turbin angin yang mencerminkan karakteristik dan kinerja dari turbin angin $1 \mathrm{~kW}$ di PLTH seperti ditunjukkan Gamabr 3. Salah satu bagian utama PLTH adalah turbin angin, yang berfungsi mengkonversikan energi angin menjadi energi mekanis. Bagian kedua adalah PMSG yang berfungsi mengkonversikan energi mekanis menjadi energi listrik.

Bagian ketiga adalah penyarah yang berfungsi untuk menyearahkan listrik AC 3 fasa keluaran PMSG menjadi listrik DC. Daya keluaran dari sistem turbin angin dimaksimalkan oleh boost converter dan MPPT .

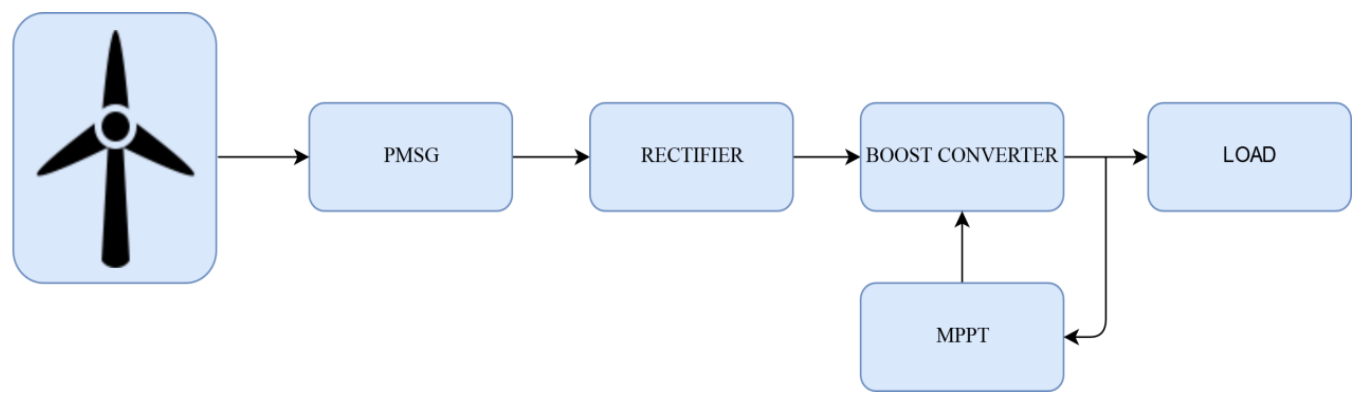

Gambar 3. Diagram blok sistem turbin angin

Untuk mendapatkan daya keluaran maksimal dari sistem turbin angin, digunakan MPPT dengan algoritma PSO. Tegangan dan arus keluaran menjadi masukan bagi algoritma PSO untuk mengevalusai duty cyle pada bagian kendali boost converter. Pada algoritma PSO digunakan swarm dari tiga partikel dengan nilai duty cycle mula-mula. Setelah nilai duty cycle dimasukkan pada boost converter maka akan didapatkan nilai daya keluaran. Masing-masing nilai duty cycle dari hasil perkalian tegangan dan arus keluaran boost converter, dianalisis untuk dilakukan penentuan nilai lokal maksimum untuk megevaluasi duty cycle. Nilai lokal maksimum dan global maksimum menentukan kecepatan partikel yang baru. Dengan demikian posisi partikel akan terus diperbaharui sehingga didapatkan daya keluaran yang paling optimal.

Untuk mengetahui pengaruh perubahan nilai parameter yang sifatnya fluktuatif terhadap hasil optimasi, akan dilakukan analisis sensitivitas. Analisis sensitivitas ditunjukkan pada Tabel 1. Parameter yang sifatnya tetap pada optimasi daya keluaran turbin angin adalah kapasitas daya turbin angin. Pengaruh perubahan parameter kecepatan turbin angin terhadap hasil optimasi diuji dengan memvariasikan kecepatan angin yaitu antara $4 \mathrm{~m} / \mathrm{s}$ hingga $11 \mathrm{~m} / \mathrm{s}$ dengan kapasitas turbin angin tetap yaitu $1000 \mathrm{~W}$.

Kecepatan angin yang berubah-ubah terhadap waktu menyebabkan daya listrik yang dihasilkan sistem turbin angin juga mengalami perubahan, seperti ditunjukan pada Tabel 2. Hal ini dikarenakan daya mekanis turbin angin dipengaruhi oleh kecepatan angin sebagaimana dinyatakan dalam Persamaan (1). Dari persamaaan tersebut, jika kecepatan angin semakin besar maka daya mekanis turbin angin akan semakin besar pula. Dan semakin besar daya mekanis turbin angin akan berakibat semakin besarnya kecepatan putar rotor. Dikarenakan turbin angin terkopel dengan PMSG maka kecepatan putar rotor semakin besar akan berakibat pada semakin besarnya pula daya listrik keluaran turbin angin. Maka grafik yang menunjukkan hubungan antara kecepatan angin dengan daya keluaran sistem turbin angin memiliki tren grafik eksponensial positif. Pada Tabel 2 
kecepatan angin yang disimulasikan hanya sampai dengan $11 \mathrm{~m} / \mathrm{s}$. Hal ini dikarenakan pada kondisi nyata kecepatan angin yang muncul hanya berkisar pada kecepatan 4-11 m/s. Jika kecepatan angin lebih dari $11 \mathrm{~m} / \mathrm{s}$ tentu akan memberikan daya keluaran yang lebih besar.

Tabel 1. Uji sensitivitas Algoritma PSO

\begin{tabular}{|c|c|c|c|}
\hline $\begin{array}{c}\text { Kecepatan } \\
\text { angin }(\mathrm{m} / \mathrm{s})\end{array}$ & $\begin{array}{c}\text { Daya output } \\
(\mathrm{W})\end{array}$ & $\begin{array}{c}\text { Daya input } \\
(\mathrm{W})\end{array}$ & $\begin{array}{c}\text { Efisiensi } \\
(\%)\end{array}$ \\
\hline 4,5 & 47,6 & 49,6 & 95,97 \\
\hline 6,5 & 254 & 295 & 86,10 \\
\hline 7 & 334,2 & 364 & 91,81 \\
\hline 8,5 & 866 & 889 & 97,41 \\
\hline 9 & 1100 & 1212 & 90,47 \\
\hline 10 & 1472 & 1676 & 87,83 \\
\hline 11 & 1596 & 1599 & 99,81 \\
\hline \multicolumn{4}{|c|}{ Rata-rata efisiensi } \\
\hline
\end{tabular}

Tabel 2. Pengaruh kecepatan angin terhadap kecepatan rotor dan daya keluaran

\begin{tabular}{|c|c|c|}
\hline $\begin{array}{c}\text { Kecepatan angin } \\
(\mathrm{m} / \mathrm{s})\end{array}$ & $\begin{array}{c}\text { Kecepatan rotor } \\
(\mathrm{rpm})\end{array}$ & $\begin{array}{c}P_{\text {out }} \\
(\mathrm{W})\end{array}$ \\
\hline 4 & 112,12 & 47,6 \\
\hline 6,5 & 150,01 & 254 \\
\hline 7 & 206,83 & 334,2 \\
\hline 8 & 244,74 & 866 \\
\hline 9 & 271,29 & 1100 \\
\hline 10 & 324,38 & 1472 \\
\hline 11 & 334,04 & 1596 \\
\hline
\end{tabular}

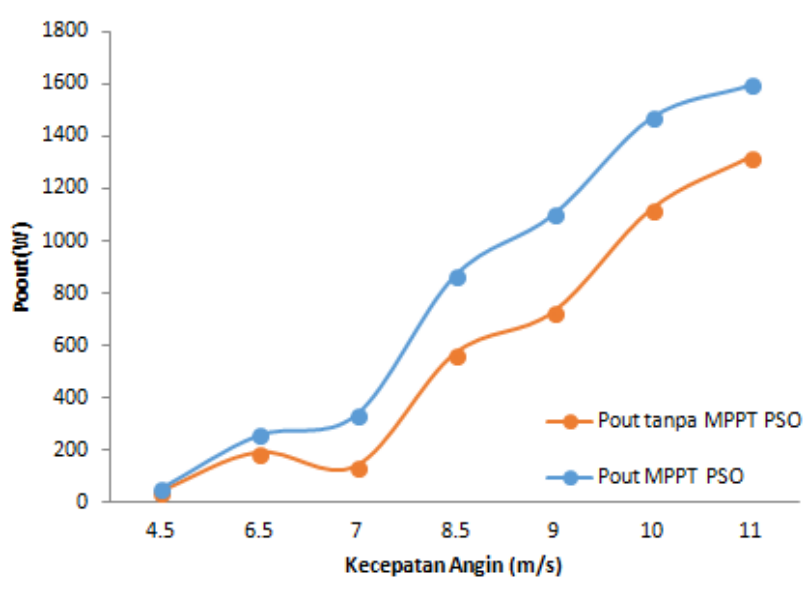

Gambar 4. Grafik antara kecepatan angin dan besar daya keluaran

Sebagaimana telah diketahui sebelumnya bahwa kecepatan angin yang berubah-ubah akan menghasilkan daya listrik yang berbeda pula. Pada penelitian [9], dijelaskan bahwa ketika kecepatan angin berbeda-beda maka akan terdapat titik optimal yang berbeda pula. Di mana daya listrik keluaran sistem turbin angin berada pada titik maksimal. 


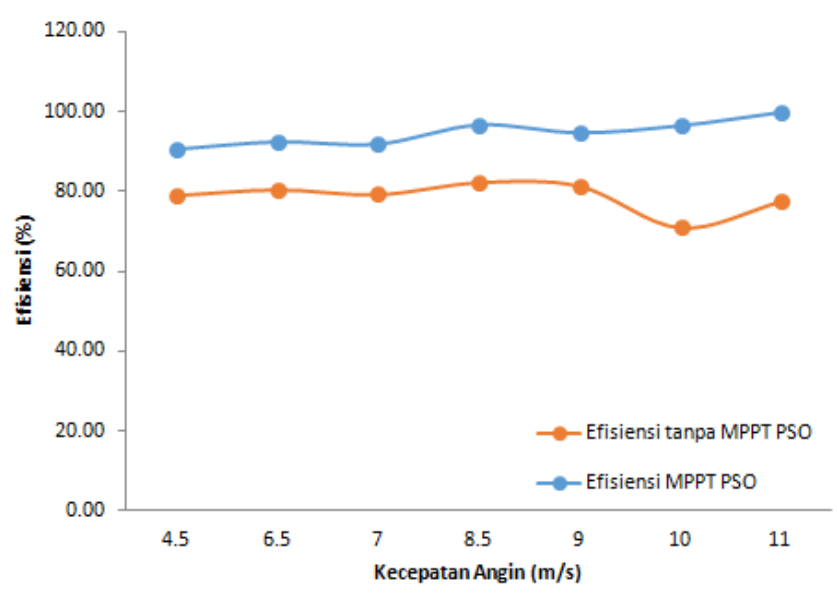

Gambar 5. Grafik antara kecepatan angin dan besar efisiensi

Pada penelitian ini digunakan MPPT dengan mengaplikasikan algoritma PSO. Hal ini bertujuan untuk menjaga agar sistem pada turbin angin selalu dapat menghasilkan daya keluaran yang maksimal. Dengan demikian efisiensi dari sistem turbin angin dapat meningkat, dan juga memiliki daya keluaran yang konstan. Hal ini terlihat jika dibandingkan dengan sistem turbin angin yang tidak menggunakan MPPT sebagaimana ditunjukan pada Gambar 4.

Berdasarkan Gambar 4, dengan pengimplementasian MPPT dengan PSO dapat dihasilkan daya listrik yang lebih besar dibanding dengan daya listrik tanpa diimplementasikan MPPT dengan PSO. Pada nilai efisiensi yang ditunjukkan oleh Gambar 5, sistem turbin angin yang tidak menggunakan MPPT PSO memiliki nilai efisiensi yang bervariasi antara 71-83 \%. Sedangkan turbin angin yang menggunakan MPPT dengan algoritma PSO memiliki efisiensi di atas 90\% dan cenderung konstan.

\section{Kesimpulan}

Sistem turbin angin yang disimulasikan ulang dan dilengkapi dengan MPPT dengan menggunakan metode algoritma PSO mampu bekerja dan beradaptasi ketika kecepatan angin berubah-ubah. Saat kecepatan angin $4,5 \mathrm{~m} / \mathrm{s}$ daya listrik keluaran yang dihasilkan sebesar $47,6 \mathrm{~W}$, sedangkan saat kecepatan angin bernilai $11 \mathrm{~m} / \mathrm{s}$ daya listrik keluaran yang dihasilkan sebesar $1596 \mathrm{~W}$. Penggunaan MPPT dengan metode algoritma PSO pada sistem turbin angin menghasilkan daya listrik yang lebih besar dibanding tidak menggunakan MPPT dengan metode algoritma PSO. Hasil implementasi MPPT dengan algoritma PSO pada sistem turbin angin menunjukan kualitas yang baik. Terjadi peningkatan daya keluaran sebesar $27,73 \%$ saat kecepatan angin yang berubah-ubah. Nilai efisiensi meningkat $17 \%$ setelah melakukan optimasi menggunakan algoritma PSO pada MPPT sistem turbin angin.

\section{Daftar Pustaka}

[1] Kementerian ESDM, “Blueprint Pengelolaan Energi 2006 -2025,” 2006.

[2] M. Hutapea, "Solusi Listrik Off Grid Berbasis Energi Terbarukan di Indonesia: 
Kerangka Regulasi dan Program," pp. 1-32, 2016.

[3] Dita Anggraini, "Analisis Potensi Angin Di Pantai Baru Pandansimo Kabupaten Bantul," September, 2016.

[4] A. N. dkk Hidayatullah, "Optimalisasi Daya Pembangkit Listrik Tenaga Angin Turbin Sumbu Horizontal dengan Menggunakan Metode Maximum Power Point Tracker," J. Electr. Electron. Control Automot. Eng., vol. 1, no. 1, pp. 7-12, 2016.

[5] D. R. Mushthafa and V. Lystianingrum, “Optimasi Sistem Pembangkit Listrik Tenaga Angin Menggunakan Maximum Power Point Tracker (MPPT) dengan Metode Gradient Approximation," vol. 1, pp. 1-6.

[6] M. Narayana, G. A. Putrus, M. Jovanovic, P. S. Leung, and S. McDonald, "Generic maximum power point tracking controller for small-scale wind turbines," Renew. Energy, vol. 44, pp. 72-79, 2012.

[7] S. Hadi et al., "Model Distribusi Kecepatan Angin untuk Peramalan Gelombang dengan Menggunakan Metode Darbyshire dan Smb di Perairan Semarang," Bul. Oseanografi Mar. April, vol. 1, no. April, pp. 25-32, 2012.

[8] Y. Megantara, "Optimasi Manajemen Daya Pada Sistem Hibrida Antara Turbin Angin, Fotovoltaik, dan Fuel cell Pada Studi Kasus kwasan Watu Ulo.," 2015.

[9] K. D. Pribadi, "Optimasi Sistem Hybrid Pembangkit listrik Tenaga Angin Dan Pembangkit Listrik Tenaga Ombak," Universitas Gadjah Mada, 2017.

[10] “No Title.” [Online]. Available: http://synergyfiles.com/2017/02/frequently-askedquestions-wind-turbine/. [Accessed: 01-Dec-2018].

[11]N. Madani, “Design of a Permanent Magnet Synchronous Generator for a Vertical Axis Wind Turbine Design of a Permanent Magnet Synchronous Generator for a Vertical Axis Wind Turbine," Thesis, Royal Institute of Technolgy, Sweden, pp. 5-46, 2011.

[12]E. Rogers, "Understanding Buck Power Stages in Switchmode Power Supplies," Application Report, March, p. 36, 1999.

[13]E. Rogers, “Understanding Buck-Boost Power Stages in Switch Mode Power Supplies," Power, vol. 18, November, pp. 1-32, 2002.

[14]K. Ishaque, Z. Salam, M. Amjad, and S. Mekhilef, "An improved particle swarm optimization (PSO)-based MPPT for PV with reduced steady-state oscillation," IEEE Trans. Power Electron., vol. 27, no. 8, pp. 3627-3638, 2012.

[15]Z. Chen, J. M. Guerrero, and F. Blaabjerg, "A review of the state of the art of power electronics for wind turbines," IEEE Trans. Power Electron., vol. 24, no. 8, pp. 1859-1875, 2009.

[16]B. Santosa, “Tutorial Particle Swarm Optimization," pp. 1-15.

[17]Y. S. Kim, I. Y. Chung, and S. Il Moon, "Tuning of the PI controller parameters of a PMSG wind turbine to improve control performance under various wind speeds," Energies, vol. 8, no. 2, pp. 1406-1425, 2015.

[18]M. Otong and R. M. Bajuri, "Maximum Power Point Tracking ( MPPT ) Pada Sistem Pembangkit Listrik Tenaga Angin Menggunakan Buck-Boost Converter," Setrum, vol. 5, no. 2, 2016. 